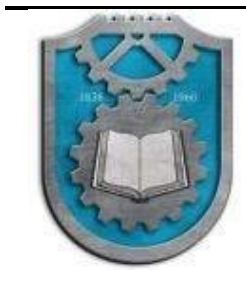

MOBILITY \& VEHICLE MECHANICS

DOI: $10.24874 / \mathrm{mvm} .2021 .47 .04 .04$

UDC: 620.97

\title{
MEASUREMENT OF RECOVERY ELECTRICITY ON THE E-BUS HIGER KLQ6125GEV3 ON EKO 1 LINE IN BELGRADE AND IMPACT ON ENERGY EFFICIENCY
}

\author{
Slobodan Mišanovic ${ }^{1}$, Dragan Taranović ${ }^{2}$, Pavle Krstić ${ }^{3}$, Dušan Živić ${ }^{4}$
}

Received in July $2020 \quad$ Revised in August $2020 \quad$ Accepted in September 2020

RESEARCH ARTICLE

\begin{abstract}
One of the most important features of an electric bus (E-bus) is the ability to recover electricity generated during the braking and deceleration phase of the vehicle's movement. The specificity of the bus operation in urban transport is reflected in the dynamic mode of vehicle's operation, especially in terms of frequency and intensity of acceleration and braking. Recovered electricity during the braking and deceleration phase of E-bus drive is determined by the performance of the drive electric motor, the strategy choice (algorithm) for regenerative braking control, driving cycle, terrain configuration, the ability of the supercapacitor to receive as much electricity as possible and the driving style of the driver. The researches of the electricity recovered on the EKO 1 line was performed in 2018 and 2019. The time of year has been chosen when heating and air-conditioning systems were not used or minimally used only in certain periods of the day, in order to more realistically look at the effect of the achieved recovery and the impact on the energy efficiency of the E-bus. The measured values of the supercapacitor voltage, the discharge and recuperation current of the supercapacitor and the SOC (State of Charge) values were taken from the SD memory card BMS (Battery Management System) of the control unit that performs data acquisition from the V-CAN of the E-bus. The value of the recovered electricity, under the assumption that the regenerative braking system is used correctly, is mostly affected by the terrain configuration, i.e. the presence of inclined sections.
\end{abstract}

KEY WORDS: E-bus, recovered electricity, energy efficiency

(C) 2021 Published by University of Kragujevac, Faculty of Engineering

\footnotetext{
${ }^{I}$ Slobodan Mišanović, Project manager, City Public Transport Company "Belgrade“, Kneginje Ljubice 29, 11000 Belgrade, PhD candidate, University of Kragujevac, Faculty of Engineering, slobodan.misanovic@gsp.co.rs (*Corresponding author)

${ }^{2}$ Dragan Taranovic, PhD, assoc. prof., University of Kragujevac, Faculty of Engineering,, E-mail: tara@kg.ac.rs

${ }^{3}$ Pavle Krstić, Project manager, City Public Transport Company “Belgrade“, Kneginje Ljubice 29,

11000 Belgarde,E-mail: pavle.krstic@gsp.co.rs

${ }^{4}$ Dušan Živić, Technical director for the electrical subsystem, City Public Transport Company

"Belgrade", Kneginje Ljubice 29, 11000 Belgarde,E-mail: dusan.zivic@gsp.co.rs
} 


\section{MERENJE OBNOVLJIVE ELEKTRIČNE ENERGIJE NA E-AUTOBUSU HIGERU KLK6125GEV3 NA EKO 1 LINIJI U BEOGRADU I UTICAJ NA ENERGETSKU EFIKASNOST}

REZIME: Jedna od najvažnijih karakteristika električnog autobusa (E-bus) je mogućnost regeneracije električne energije proizvedene tokom faze kočenja i usporavanja vozila. Specifičnost rada autobusa u gradskom saobraćaju ogleda se u dinamičkom načinu rada vozila, posebno u pogledu učestalosti i intenziteta ubrzanja i kočenja. Obnovljena električna energija tokom faze kočenja i usporavanja pogona E-autobusa određena je performansama pogonskog elektromotora, izborom strategije (algoritmom) za kontrolu regenerativnog kočenja, ciklusom vožnje, konfiguracijom terena, sposobnošću superkondenzatora da primi što više električne energije i načina vožnje vozača. Istraživanja obnovljive električne energije na liniji EKO 1 vršena su 2018. i 2019. Izabrano je doba godine kada se sistemi grejanja i klimatizacije nisu koristili ili su se minimalno koristili samo u određenim periodima dana, kako bi se realno sagledali efekat postignutog oporavka i uticaj na energetsku efikasnost E-autobusa. Izmerene vrednosti napona superkondenzatora, struje pražnjenja i rekuperacije superkondenzatora i SOC (stanje napunjenosti) preuzete su sa SD memorijske kartice BMS (Sistem za upravljanje baterijom) upravljačke jedinice koja vrši prikupljanje podataka sa V-CAN E-autobusa. Na vrednost obnovljene električne energije, pod pretpostavkom da se sistem regenerativnog kočenja pravilno koristi, najviše utiče konfiguracija terena, odnosno prisustvo deonica pod nagibom.

KLJUČNE REČI: E-autobus, obnovljena električna energija, energetska efikasnost 


\title{
MEASUREMENT OF RECOVERY ELECTRICITY ON THE E-BUS HIGER KLQ6125GEV3 ON EKO 1 LINE IN BELGRADE AND IMPACT ON ENERGY EFFICIENCY
}

\author{
Slobodan Mišanović, Dragan Taranović, Pavle Krstić, Dušan Živić
}

\section{INTRODUCTION}

The operation of the electric bus drive system is characterized by typical operating modes: vehicle acceleration mode to reach the set vehicle's speed, constant speed driving, and vehicle deceleration and braking mode. Electric and mechanical power flows when the vehicle is in acceleration mode are shown in Figure 1 (a), while the mechanical and electric power flows in braking mode are shown in Figure 1 (b) [1]. An electric generator is an electric drive motor in regenerative braking mode (recuperation).

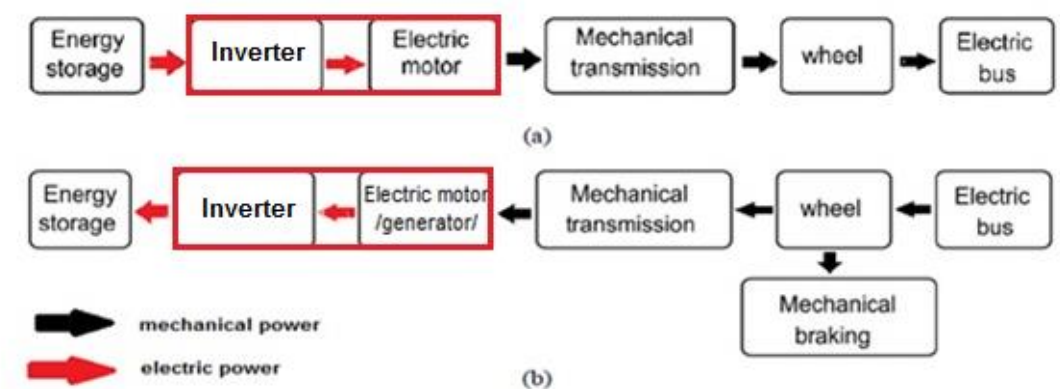

Figure 1 Electrical and mechanical power flows

The required power of the electric motor for the movement of the E-bus and the consumed electricity depends on the load of the vehicle, the resistance forces that occur in the phase of the movement (rolling resistance, grade resistance, aerodynamic and inertial resistance) and speed. The achieved energy recovery in the E-bus in the braking and deceleration phase is determined by the performance of the electric drive, the choice of regenerative braking control strategy (algorithm), driving cycle, terrain configuration, battery/supercapacitor to receive as much current as possible and driving style. According to the recommendations of the vehicle manufacturer "Higer" for the electric bus KLQ6125GEV3, the highest energy recovery in the braking phase and energy efficiency is achieved [2]:

- When the E-bus is moved at speed of about $30 \div 35 \mathrm{~km} / \mathrm{h}$.

- When the drive electric motor operates with the highest efficiency, when the "rpm"' is above $2000 \mathrm{~min}^{-1}$.

- When the command of service brake is depressed up to $28 \%$ of the pedal stroke, because the optimal recovery corresponds to a command angle of $9^{\circ}$ (maximum angle is $32^{\circ}$ ), which represents $28 \%$ of the brake pedal stroke.

- When the E-bus moves with a speed higher than $5 \mathrm{~km} / \mathrm{h}$, while the engine speed is greater than $600 \mathrm{~min}^{-1}$,

- When the deceleration of E-bus is inertial, the braking torque generated by the electric motor has constant value up to $34 \mathrm{Nm}$ and acts on the drive wheels axles. 
By reducing the speed of the electric motor to $200 \mathrm{~min}^{-1}$, there is a gradual reduction of braking torque up to a value of $0 \mathrm{Nm}$.

- Manufacturer of buses 'Higer', states that a better recuperation effect is achieved by activating the service brake up to $28 \%$ of the pedal stroke than by decelerating by inertia under the same conditions in terms of achieved speed before direct braking/deceleration by inertia and duration of braking/deceleration by inertia.

- In cases when the service brake is depressed more than $28 \%$ of the pedal stroke, the activity is present of regenerative braking on the wheels of the drive axle, and the pneumatic system of the vehicle that acts on the wheels of the steering and drive axles. In this case, it is reduced regenerative braking efficiency.

- When driving downhill, it is recommended applying light pressure on the service brake pedal in order to activate regenerative braking and to maintain a constant speed of movement for the vehicle, thus achieving the best effect of electricity recovery.

The aim of this paper is to investigate the realized recovery energy on the EKO 1 line in real working conditions and the influence of factors, primarily terrain configuration, and driving style.

\section{THEORETICAL BASES OF MOVEMENT AND REGENERATIVE BRAKING OF E-BUS}

When the E-bus is in acceleration mode, the forces and power are represented by the equations:

$$
\begin{gathered}
F_{v u}=F_{f}+F_{v} \pm F_{u}+F_{a} \\
P_{\text {mov }}=\left(F_{f}+F_{v} \pm F_{u}+F_{a}\right) \cdot v_{\text {ebus }}
\end{gathered}
$$

$F_{v u}$ - traction force on drive wheels $[\mathrm{N}]$

$F_{f}$ - rolling resistance force $[\mathrm{N}]$

$F_{v}$ - aerodynamic resistance force $[\mathrm{N}]$

grade resistance force (rise, fall) $[\mathrm{N}]$

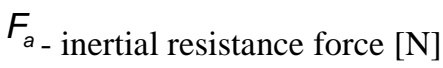

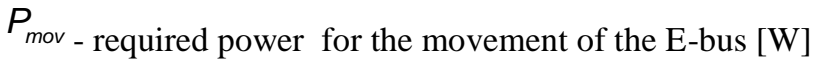

$V_{\text {ebus }}$ - speed of E-bus $[\mathrm{m} / \mathrm{s}]$.

The torque on the drive wheels is shown by equations:

$$
\sum_{j=3}^{4} M_{t j}=F_{v u} \cdot r_{d}
$$

$M_{t j}$ - the torque on the drive axle wheels [Nm] 

and impact on energy efficiency

$j=3,4$ - wheels of the drive axle

$r_{d}$ - dynamic radius of the drive wheel $[\mathrm{m}]$.

Electric current flows from the power storage source (battery or supercapacitor) and supplies the drive electric motor via an inverter, which form one unit. From the drive motor, through the transmission to the drive wheels, a flow of mechanical power is generated. These flows are represented by the equations.

$$
\begin{gathered}
P_{u c d} \cdot \eta_{u c}=P_{e m} \\
P_{e m} \cdot \eta_{i} \cdot \eta_{e m} \cdot \eta_{t}=\frac{M_{e m} \cdot i_{t} \cdot v_{e b u s}}{r_{d}} \cdot \eta_{t}=\sum_{j=3}^{4} M_{t j} \cdot \omega_{t j}
\end{gathered}
$$

$P_{u c d}$ - storage power for driving of discharge (supercapacitor, battery) during acceleration [W]

$P_{e m}$ - the power of the driving electric motor [W]

$M_{e m}$ - the torque of the driving electric motor (traction mode) $[\mathrm{Nm}]$

$\eta_{u c}$ - coefficient of storage efficiency and internal losses

$\eta_{e m}$ - coefficient of efficiency of the driving electric motor (traction mode)

$\eta_{i}$ - coefficient of inverter efficiency

$\eta_{t}$ - coefficient of transmission efficiency

$i_{t}$ - total transmission ratio

$\omega_{t j}$ - angular velocity of the drive axle wheels $[\mathrm{rad} / \mathrm{s}]$

$\omega_{t j}$ - angular velocity of the drive axle wheels $[\mathrm{rad} / \mathrm{s}]$.

Power of the electric motor is proportional to the size of the current and voltage, according to the load and operating modes (acceleration, motion with constant velocity).

$$
P_{e m}=U_{t} \cdot I_{t}
$$

- current value of electric motor voltage [V]

- current value of electric motor current [A].

The power of electrical losses in the electric motor and inverter depends on the coefficient of efficiency of these two systems is represented by the equation.

$$
P_{g e m}=P_{u c d} \cdot \eta_{u c}-P_{u c d} \cdot \eta_{u c} \cdot \eta_{i} \cdot \eta_{e m}=P_{u c d} \cdot \eta_{u c} \cdot\left(1-\eta_{i} \cdot \eta_{e m}\right)
$$

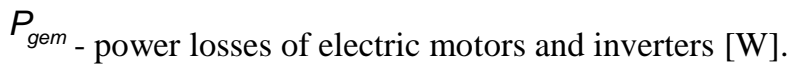


If the operation of the propulsion electric motor is observed in the mode of acceleration of the vehicle or movement at a constant speed in a certain time interval, the consumed electricity can be represented by the equation:

$$
E_{e m}=\int_{t_{1}}^{t_{2}} U_{t i} \cdot I_{t i} \cdot d t
$$

$$
\begin{aligned}
& E_{e m \text {-electricity consumed of driving electric motor }} \\
& t_{1} \text { - start time [s] } \\
& t_{2} \text { - end time [s]. }
\end{aligned}
$$

From the aspect of total engaged electric power: electric motor drive, auxiliary devices, air conditioning and heating systems, as well as losses that occur in the drive electric motor, inverter, battery and electrical installation, it is represented by the equation:

$$
P_{\text {ebus }}=P_{e m}+P_{p u}+P_{a c}+P_{h}+P_{g e m}+P_{g b k}
$$

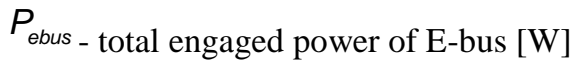

$P_{p u}$ - engaged power auxiliary equipment E-bus [W]

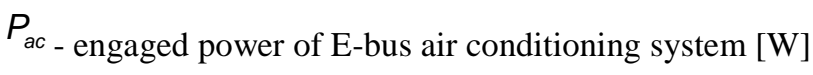

$P_{h}$ - engaged power of the E-bus heating system [W]

$P_{g b k}$ - power losses in supercapacitors (batteries) and E-bus cables [W].

The total power of the drive in equation 1.9, in the time interval, gives the total energy consumed by the E-bus expressed in $\mathrm{kWh}$, which represents the energy consumed from the supercapacitor (battery) in the acceleration phase represented by the equation:

$$
E_{p_{u c}}=\frac{1}{3600000 \cdot \eta_{u c}} \int_{t_{1}}^{t_{2}}\left(P_{e m}+P_{g e m}+P_{p u}+P_{a c}+P_{h}\right) \cdot d t
$$

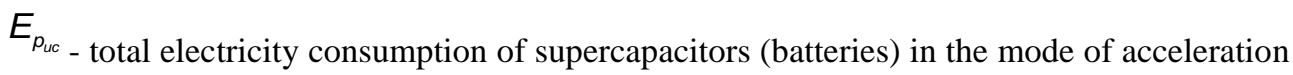
$[\mathrm{kWh}]$.

When the E-bus is in braking mode, total braking power is shown in the following equation:

$$
P_{k i}+P_{k j}+P_{r k j}=\sum_{i=1}^{2} M_{k i} \cdot \omega_{k i}+\sum_{j=3}^{4} M_{k j} \cdot \omega_{k j}+\eta_{t} \sum_{j=3}^{4} M_{r k j} \cdot \omega_{k j}
$$

\footnotetext{
$P_{k i}$ - power of braking wheels on the front axle of the pneumatic system [W]

$P_{k j}$ - power of braking wheels on drive axle from the pneumatic system [W]

$P_{r k}$ - power of braking wheels on drive axle from regenerative braking [W]

$M_{k i}$ - torque of braking wheels of the front axle of the pneumatic system [Nm]
} 

and impact on energy efficiency

$M_{k j}$ - torque of braking wheels of the drive axle of the pneumatic system [Nm]

$M_{r k j}$ - torque of braking wheels of the drive axle by regenerative braking [Nm]

$\omega_{k i}$ - angular velocity of the front axle wheels $[\mathrm{rad} / \mathrm{s}]$

$\omega_{k j}$ - angular velocity of the drive axle wheels $[\mathrm{rad} / \mathrm{s}$ ]

$i=1,2$ - wheels of the front axle.

When the E-bus brakes only with regenerative braking $\left(P_{k i}=P_{k j}=0\right)$ the mechanical power of the E-bus, which is transmitted to the drive electric motors via drive wheels and transmission, is represented by the equation:

$$
\eta_{t} \sum_{j=3}^{4} \frac{M_{r k j} \cdot v_{e b u s} \cdot i_{t}}{r_{d}}=P_{r k}
$$

The electrical power generated by the drive motor is equal to:

$$
P_{\text {emg }}=\frac{M_{e m r} \cdot v_{\text {ebus }} \cdot i_{t}}{r_{d}}
$$

So the equation is:

$$
\eta_{t} \sum_{j=3}^{4} \frac{M_{r k j} \cdot v_{\text {ebus }} \cdot i_{t}}{r_{d}}=\frac{M_{\text {emr }} \cdot v_{\text {ebus }} \cdot i_{t}}{r_{d}}
$$

$P_{\text {emg }}$ - power of electric drive motor in regenerative braking mode (recuperation, generator mode) $[\mathrm{W}]$;

$M_{e m r}$ - torque of the drive electric motor in regenerative braking mode [Nm].

The power of the electric motor in generator mode represented by the current and voltage has the form:

$$
P_{\text {emg }}=U_{t} \cdot l_{t r}
$$

$U_{t}$ - current value of electric motor voltage $[\mathrm{V}]$;

$I_{t r}$ - current value of electric motor regeneration current [A].

The power of electrical losses in the electric motor and inverter in generator mode can be represented by the equation:

$$
P_{g e m r}=P_{e m g} \cdot\left(1-\eta_{e m r} \cdot \eta_{i}\right)
$$

$P_{\text {gemr }}$ - power losses in the electric motor and inverter in generator mode [W]; 


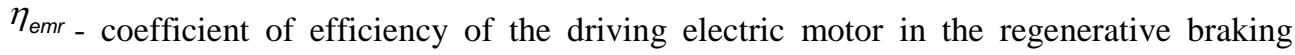
mode (recuperation).

The output electric power (recuperation power) from the drive electric motor and inverter in the generator mode expressed in terms of current values of current and voltage and losses is shown by the equation:

$$
P_{e m r}=U_{t} \cdot I_{t r} \cdot \eta_{e m r} \cdot \eta_{i}
$$

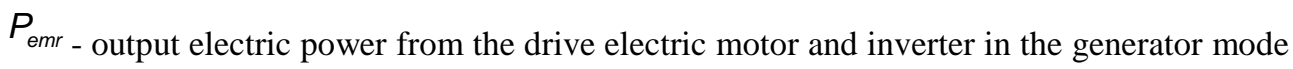
[W].

During regenerative braking in a time interval, the electricity that is generated and that can be stored in the source of electricity storage (supercapacitor, battery) expressed in $\mathrm{kWh}$, is represented by the integral:

$$
E_{r_{u c}}=\frac{\eta_{u c}}{3600000} \int_{t_{1}}^{t_{2}}\left(P_{e m g}-P_{g e m r}-P_{p u}-P_{a c}-P_{h}\right) \cdot d t
$$

$E_{r_{u c}}$ - recuperation electricity stored in a supercapacitor (battery) [kWh].

The difference between the electricity consumed from the supercapacitor and the energy returned to the supercapacitor in the observation period represents the total electricity consumption of E-bus has the form:

$$
\begin{gathered}
\Delta E_{u c}=E_{P_{u c}}-E_{r_{u c}} \\
\Delta E_{u c}=E_{\text {ebus }}
\end{gathered}
$$

$\Delta E_{u c}$ - difference between the electricity consumed from the supercapacitor and the energy returned to the supercapacitor in the observation period [kWh]

$E_{\text {ebus }}$ - total electricity consumption of E-bus in the observation period [kWh].

The efficiency of regenerative braking of electric buses can be expressed as the ratio of electricity generated in the recovery phase to the consumed electricity in the phase of acceleration and driving at a constant speed using the expression.

$$
\lambda_{u c}=\frac{E_{r_{u c}}}{E_{p_{u c}}} \cdot 100
$$

$\lambda_{u c}$ - coefficient of efficiency of recovery [\%].

If divide the difference between the electricity consumed from the supercapacitor and the energy returned to the supercapacitor in the observation period by the distance travelled by the E-bus, which is usually taken as the length of the route in the direction "A" and the direction "B", the average electricity consumption of the E-bus has the form:

$$
\Delta E_{u c_{A}}=E_{P_{u c_{A}}}-E_{r_{u C_{A}}}
$$



and impact on energy efficiency

$$
\begin{aligned}
& \lambda_{u c_{A}}=\frac{E_{r_{u c_{A}}}}{E_{p_{u c_{A}}}} \cdot 100 \\
& \Delta E_{u c_{A}}=E_{\text {ebus }_{A}} \\
& E_{\text {ebus }_{A}}=\frac{\Delta E_{u c_{A}}}{L_{A}}
\end{aligned}
$$

\section{METHODOLOGY AND RESULTS OF MEASUREMENT}

The research of electricity recovered on the line EKO 1 (Vuk's monument-Belvil) in real operating conditions on a larger sample of measurements in both directions was performed on 25.06.2018, 28.06.2018, 27.09.2018, 08.10. 2019 and 09.10.2019 [2]. The average length of the EKO 1 line is $7995 \mathrm{~m}$. Depending on directions, the length of the route in the direction " $\mathrm{A}$ " is $7477 \mathrm{~m}$, where there are 15 stations with an average inter-station distance of $534 \mathrm{~m}$. In the direction "B", the length of the route is $8513 \mathrm{~m}$, where 17 stations are positioned with an average inter-station distance of $532 \mathrm{~m}$. Figure 2, shows the topography of the terrain with the elevations of the stations [3].

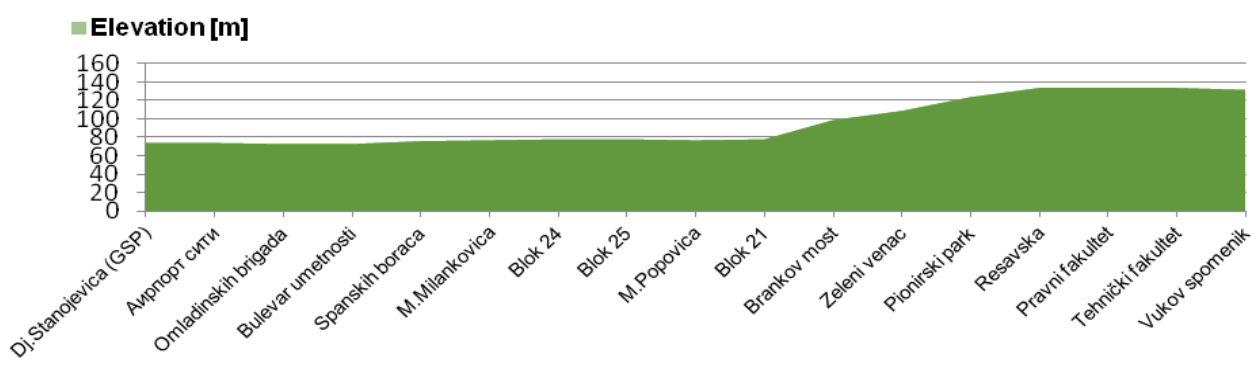

Figure 2 Characteristic of the route line EKO 1

The geometric characteristics of the route of the EKO 1 line are characterized by a distinctly flat terrain configuration in New Belgrade and the distance from the Faculty of Law to Vuk's Monument and a slight ascent of the terrain from Block 21- Branko's Bridge Brankova-King Alexander Boulevard to Resavska Street. Time of year has been chosen when the heating and air conditioning systems were not used or were used minimally only in some periods of the day when the outside temperatures were higher than $23{ }^{\circ} \mathrm{C}$ or less than $12{ }^{\circ} \mathrm{C}$, in order to see as realistically as possible the coefficient of achieved recovery. The measured values of the supercapacitor voltage, current the discharge, the recuperation current of the supercapacitor, and the SOC (State of Charge), values were taken from the SD memory card BMS (Battery Management System) of the control unit that performs data acquisition from the V-CAN bus. The BMS control unit is shown in Figure 3. 


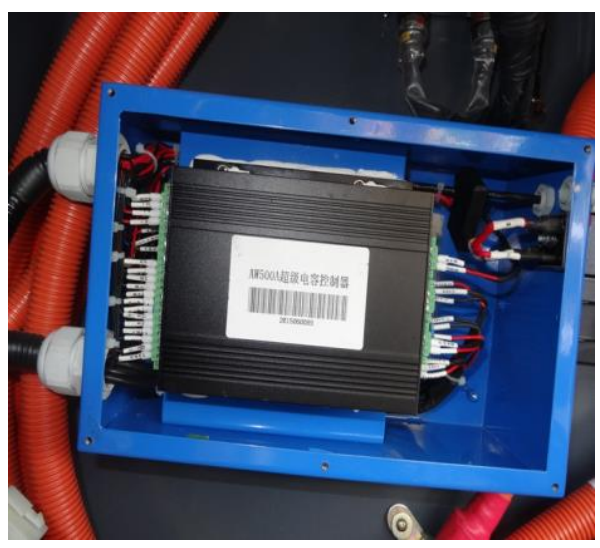

Figure 3 BMS control unit

Results of energy consumed from the supercapacitor $E_{p_{u c_{A}}}$, recuperation energy $E_{r_{u c_{A}}}$ returned to the supercapacitor, recuperation coefficient $\lambda_{u c_{A}}$, for the direction "A" (Vuk's Monument - Belvil) is shown in Table 1.

Table 1 Results of realized recovery energy and consumed energy in the supercapacitor, on line EKO 1, direction "A" (Vuk's monument-Belvil)

\begin{tabular}{|c|c|c|c|c|}
\hline Date [d-m-y] & E-bus & $T_{\text {spo }}\left[{ }^{\circ} \mathrm{C}\right]$ & $\begin{array}{c}\text { Departure time } \\
{[\mathrm{hh}: \mathrm{mm} . \mathrm{ss}]}\end{array}$ & $\begin{array}{c}\text { Arrival } \\
\text { time } \\
{[\mathrm{hh}: \mathrm{mm} . \mathrm{ss}]}\end{array}$ \\
\hline $25-06-18$ & 2104 & 14 & $7: 15: 00$ & $7: 43: 15$ \\
\hline $25-06-18$ & 2104 & 16 & $8: 49: 04$ & $9: 19: 32$ \\
\hline $25-06-18$ & 2104 & 17 & $10: 23: 33$ & $10: 50: 35$ \\
\hline $25-06-18$ & 2104 & 22 & $13: 29: 35$ & $13: 59: 13$ \\
\hline $28-06-18$ & 2104 & 17 & $7: 38: 08$ & $8: 09: 40$ \\
\hline $28-06-18$ & 2104 & 19 & $9: 12: 35$ & $9: 40: 13$ \\
\hline $28-06-18$ & 2104 & 20 & $10: 45: 58$ & $11: 13: 07$ \\
\hline $28-06-18$ & 2104 & 22 & $17: 09: 20$ & $17: 37: 42$ \\
\hline $27-09-18$ & 2105 & 13 & $10: 22: 21$ & $10: 50: 31$ \\
\hline $27-09-18$ & 2105 & 16 & $13: 31: 14$ & $14: 02: 21$ \\
\hline $27-09-18$ & 2105 & 18 & $15: 05: 21$ & $15: 39: 43$ \\
\hline
\end{tabular}


Measurement of recovery electricity on the e-bus higer klq6125gev3 on eko 1 line in Belgrade and impact on energy efficiency

\begin{tabular}{|c|c|c|c|c|}
\hline $08-10-19$ & 2103 & 16 & $16: 12: 49$ & $16: 45: 09$ \\
\hline $08-10-19$ & 2103 & 11 & $19: 29: 29$ & $20: 02: 39$ \\
\hline $09-10-19$ & 2103 & 21 & $11: 37: 36$ & $12: 10: 30$ \\
\hline $09-10-19$ & 2103 & 26 & $14: 39: 11$ & $15: 12: 01$ \\
\hline $09-10-19$ & 2103 & 25 & $16: 12: 56$ & $16: 46: 21$ \\
\hline $09-10-19$ & 2103 & 13 & $22: 26: 16$ & $23: 00: 31$ \\
\hline
\end{tabular}

Table 1 Results of realized recovery energy and consumed energy in the supercapacitor, on line EKO 1, direction "A" (Vuk's monument-Belvil)(continued)

\begin{tabular}{|c|c|c|c|c|c|}
\hline $\begin{array}{l}\text { Driving time } \\
\text { [hh:mm.ss] }\end{array}$ & $E_{p_{u c_{A}}}[\mathrm{kWh}]$ & $E_{v_{v_{A}}}[\mathrm{kWh}]$ & $\lambda_{u c_{A}[\%]}$ & $\begin{array}{c}\Delta E_{u c_{A}} \\
{[\mathrm{kWh}]}\end{array}$ & $\begin{array}{c}\boldsymbol{E}_{\boldsymbol{e b u s}_{\boldsymbol{L}_{\boldsymbol{A}}}} \\
{[\mathrm{kWh} / \mathrm{km}]}\end{array}$ \\
\hline $0: 28: 15$ & 9.150 & 2.040 & 22.30 & 7.110 & 0.952 \\
\hline $0: 30: 28$ & 8.220 & 1.780 & 21.65 & 6.440 & 0.862 \\
\hline 0:27:02 & 7.948 & 1.915 & 24.09 & 6.033 & 0.808 \\
\hline 0:29:38 & 10.075 & 2.066 & 20.51 & 8.009 & 1.072 \\
\hline $0: 31: 32$ & 9.716 & 2.255 & 23.21 & 7.461 & 0.999 \\
\hline $0: 27: 41$ & 9.433 & 2.693 & 28.55 & 6.740 & 0.902 \\
\hline 0:27:09 & 8.925 & 2.435 & 27.28 & 6.490 & 0.869 \\
\hline $0: 28: 22$ & 11.302 & 2.285 & 20.22 & 9.017 & 1.207 \\
\hline 0:28:10 & 9.163 & 2.593 & 28.30 & 6.570 & 0.880 \\
\hline 0:31:07 & 8.956 & 2.387 & 26.65 & 6.569 & 0.879 \\
\hline $0: 34: 22$ & 9.889 & 2.466 & 24.94 & 7.423 & 0.994 \\
\hline 0:32:20 & 11.817 & 2.642 & 22.36 & 9.175 & 1.228 \\
\hline $0: 33: 10$ & 10.073 & 1.893 & 18.79 & 8.180 & 1.095 \\
\hline $0: 32: 54$ & 9.236 & 2.273 & 24.61 & 6.963 & 0.932 \\
\hline $0: 32: 50$ & 12.522 & 2.098 & 16.75 & 10.424 & 1.395 \\
\hline
\end{tabular}




\begin{tabular}{|c|r|r|r|r|r|}
\hline $0: 33: 25$ & 11.882 & 2.309 & 19.43 & 9.573 & 1.282 \\
\hline $0: 34: 15$ & 9.504 & 2.352 & 24.75 & 7.152 & 0.957 \\
\hline
\end{tabular}

The highest value of recuperation energy achieved by the E-bus in the direction " $\mathrm{A}$ " is 2.693 $\mathrm{kWh}$ (28.06.2018, period from 9:12:35 to 9:40:13), the lowest value is $1.780 \mathrm{kWh}$ (25.06.2018, period from 8:49:04 to 9:19:32), while the average value for all shown measurements of the realized recovery energy returned to the supercapacitor is $2.264 \mathrm{kWh}$. Analyse the ratio of realized energy recovery and the total electricity consumed by coefficients supercapacitor recovery $\lambda_{u c_{A}}$ it can be concluded that its maximum value is $28.55 \%$, a minimum of $16.75 \%$ and the average value realized in the direction "A" $23.20 \%$. Graphic of measured values of supercapacitor voltage, supercapacitor charging/discharging current and SOC when the maximum recovery energy of $2.693 \mathrm{kWh}$ was achieved, on the E-bus v.n. 2104 (28.06.2018, from 9:12:35 to 9:40:13), is shown in Figure 4.

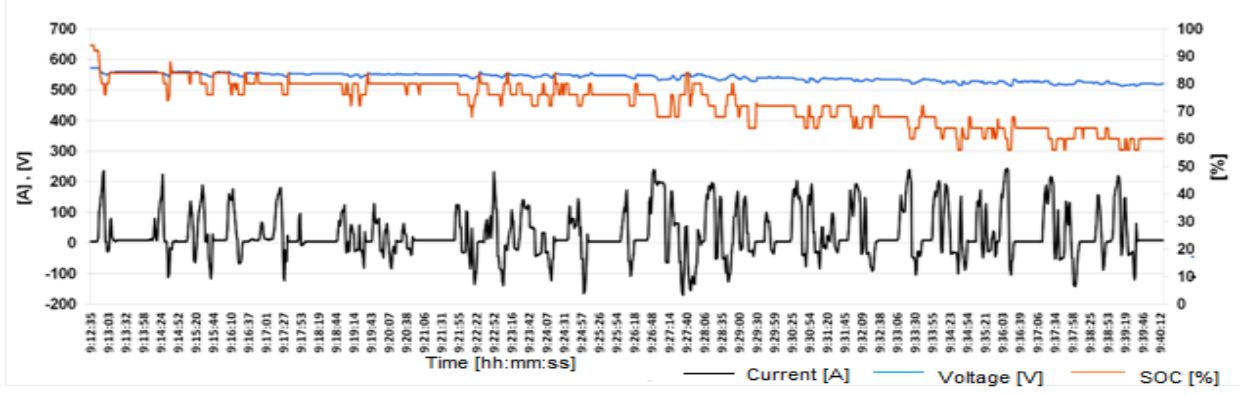

Figure 4 Values the voltage, current and SOC of supercapacitors in the period 9:12:35 to 9:40:13, direction "A", 28.06.2018

At the time of braking the E-bus, the maximum recovery current was $171.1 \mathrm{~A}$ at 9:27:29, at an E-bus speed of $46.9 \mathrm{~km} / \mathrm{h}$. Driving cycles that E-bus v.n. 2104 is achieved in the period from 9:12:35 to 9:40:13, is shown in Figure 5.

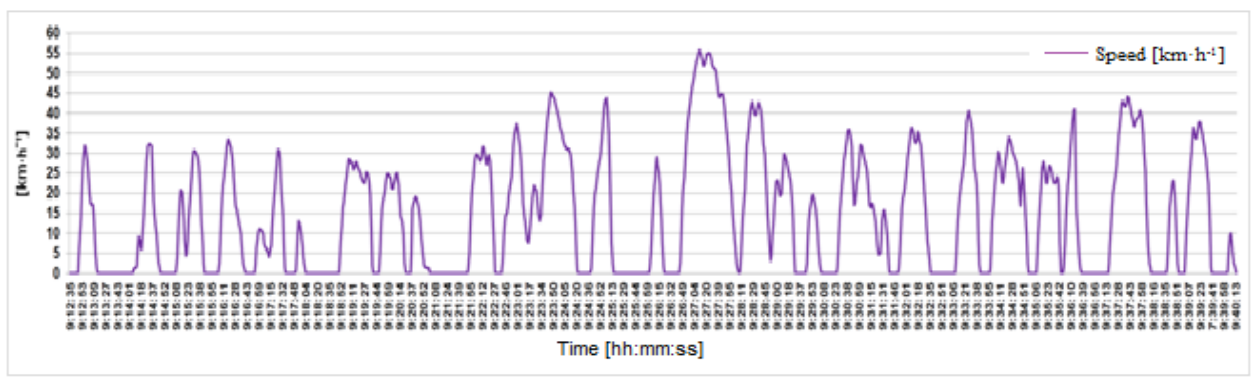

Figure 5 Values the speed of E-bus in the period 9:12:35 to 9:40:13, direction ', A', 28.06.2018

From Figure 5, the driving time in the direction of "A" in the specified time period was 27 minutes and 40 seconds (00:27:40), which indicates the optimal traffic conditions, without traffic jams and delays, which was a prerequisite that E-bus reaches several times over 40 $\mathrm{km} / \mathrm{h}$, on Branko's bridge maximum speed was $55.2 \mathrm{~km} / \mathrm{h}$, which gave the E-bus great 

and impact on energy efficiency

kinetic energy in the braking phase and the ability to generate a recovery current from $150 \mathrm{~A}$ to 171.1 A. For direction "B" (Belvil-Vuk's monument), the results of the energy consumed from the supercapacitor $E_{p_{u c B}}$, energy recovery $E_{r_{u c B}}$ which is returned to the supercapacitor, the recovery coefficient $\lambda_{u c_{B}}$, is shown in Table 2. In the direction "B" the highest value of recuperation energy generated by the E-bus is $2.510 \mathrm{kWh}(28.06 .2018$, in the period from $6: 47: 21$ to $7: 18: 46)$, the lowest value is $1.311 \mathrm{kWh}(09.10 .2019$, period from $5: 56: 01$ to $6: 30: 16$ ), while the average value of the displayed results of the recovered energy returned to the supercapacitor is $1.863 \mathrm{kWh}$. The ratio of the recovered energy and the total electricity consumed by the supercapacitor is expressed in terms of the $\lambda_{u c_{B}}$ is the maximum $19.57 \%$, minimal $9.73 \%$ and the average value $\lambda_{u c_{B}}$, which is realized in the direction " $\mathrm{B}$ " is $14.06 \%$.

Table 2 Results of realized recovery energy and consumed energy in the supercapacitor, on line EKO 1, direction "B" (Belvile-Vuk's monument)

\begin{tabular}{|c|c|c|c|c|}
\hline Date [d-m-y] & E-bus & $T_{\text {spo }}\left[{ }^{\circ} \mathrm{C}\right]$ & $\begin{array}{l}\text { Departure time } \\
\text { [hh:mm.ss] }\end{array}$ & $\begin{array}{c}\text { Arrival } \\
\text { time } \\
{[\mathrm{hh}: \mathrm{mm} . \mathrm{ss}]}\end{array}$ \\
\hline $25-06-18$ & 2104 & 13 & $6: 22: 10$ & $9^{6: 56: 5}$ \\
\hline $25-06-18$ & 2104 & 14 & 8:01:30 & $3^{8: 36: 0}$ \\
\hline $25-06-18$ & 2104 & 17 & 9:35:30 & $42^{10: 09:}$ \\
\hline $25-06-18$ & 2104 & 23 & $2^{15: 52: 0}$ & $57^{16: 31:}$ \\
\hline $28-06-18$ & 2104 & 16 & $6: 47: 21$ & $0^{7: 18: 4}$ \\
\hline $28-06-18$ & 2104 & 19 & 9:58:44 & $00^{10: 29:}$ \\
\hline 28-06-18 & 2104 & 26 & $0^{16: 18: 4}$ & 01 16:59: \\
\hline $27-09-18$ & 2105 & 14 & $9^{11: 09: 5}$ & $06^{11: 43:}$ \\
\hline $27-09-18$ & 2105 & 16 & $9^{12: 44: 1}$ & $55^{13: 17:}$ \\
\hline 27-09-18 & 2105 & 17 & $7^{14: 18: 0}$ & $39^{14: 54:}$ \\
\hline 27-09-18 & 2105 & 18 & $3^{15: 51: 3}$ & 50 \\
\hline 08-10-19 & 2103 & 16 & $9^{16: 56: 5}$ & $19^{17: 44:}$ \\
\hline 09-10-19 & 2103 & 8 & $5: 56: 01$ & $6^{6: 30: 1}$ \\
\hline 09-10-19 & 2103 & 15 & $9: 12: 26$ & $1^{9: 55: 1}$ \\
\hline 09-10-19 & 2103 & 25 & $1^{13: 53: 2}$ & $16^{14: 32:}$ \\
\hline 09-10-19 & 2103 & 24 & $1^{17: 00: 1}$ & $15^{17: 46:}$ \\
\hline
\end{tabular}


Table 2 Results of realized recovery energy and consumed energy in the supercapacitor, on line EKO 1, direction "B" (Belvile-Vuk's monument)(continued)

\begin{tabular}{|c|c|c|c|c|c|}
\hline $\begin{array}{l}\text { Driving } \\
\text { time } \\
\text { [hh:mm.ss] }\end{array}$ & $E_{p_{u A}}[\mathrm{kWh}]$ & $E_{V_{u C_{A}}}[\mathrm{kWh}]$ & $\lambda_{u c_{A}[\%]}$ & $\begin{array}{c}\Delta E_{u c_{A}} \\
{[\mathrm{kWh}]}\end{array}$ & $\begin{array}{c}\boldsymbol{E}_{\boldsymbol{e b u s}_{\boldsymbol{L}_{\boldsymbol{A}}}} \\
{[\mathrm{kWh} / \mathrm{km}]}\end{array}$ \\
\hline $0: 34: 49$ & 11.828 & 1.702 & $9^{14.3}$ & 10.126 & $26^{10.1}$ \\
\hline $0: 34: 33$ & 12.372 & 1.844 & $0^{14.9}$ & 10.528 & $28^{10.5}$ \\
\hline $0: 34: 12$ & 10.974 & 1.371 & $9^{12.4}$ & 9.603 & $3 \begin{array}{l}9.60 \\
3\end{array}$ \\
\hline $0: 39: 55$ & 14.434 & 1.866 & $3^{12.9}$ & 12.568 & $68^{12.5}$ \\
\hline $0: 31: 19$ & 13.439 & 2.510 & $8^{18.6}$ & 10.929 & $29^{10.9}$ \\
\hline $0: 30: 16$ & 12.806 & 2.506 & $7^{19.5}$ & 10.300 & $00^{10.3}$ \\
\hline $0: 40: 21$ & 17.415 & 2.480 & $4^{14.2}$ & 14.935 & $35^{14.9}$ \\
\hline $0: 33: 07$ & 12.736 & 2.333 & $2^{18.3}$ & 10.403 & $03^{10.4}$ \\
\hline $0: 33: 36$ & 11.264 & 1.732 & $8^{15.3}$ & 9.532 & $2^{9.53}$ \\
\hline $0: 36: 32$ & 12.497 & 1.931 & $\begin{array}{ll} & 15.4 \\
5 & \\
\end{array}$ & 10.566 & $66^{10.5}$ \\
\hline $0: 37: 17$ & 12.677 & 1.909 & $6^{15.0}$ & 10.768 & $68^{10.7}$ \\
\hline $0: 47: 20$ & 13.877 & 1.567 & $9^{11.2}$ & 12.310 & $10^{12.3}$ \\
\hline $0: 34: 15$ & 13.477 & 1.311 & 9.73 & 12.166 & $66^{12.1}$ \\
\hline $0: 42: 45$ & 13.764 & 1.355 & 9.84 & 12.409 & $09^{12.4}$ \\
\hline $0: 38: 55$ & 14.649 & 1.809 & $5^{12.3}$ & 12.840 & $40^{12.8}$ \\
\hline $0: 46: 04$ & 15.225 & 1.576 & $\begin{array}{ll} & 10.3 \\
5 & \\
\end{array}$ & 13.649 & $49^{13.6}$ \\
\hline $0: 34: 49$ & 11.828 & 1.702 & $9^{14.3}$ & 10.126 & $26^{10.1}$ \\
\hline
\end{tabular}

An even greater degree of recuperation in direction "A", was achieved in the "Study of the impact of driving style on the energy efficiency of the E-bus" [4], when the driver strictly applied the manufacturer's recommendations and the recommendations from the polygon test [4]. In a real drive conducted on 22.01.2020, in the period of intermediate load and optimal traffic conditions, the maximum recuperation coefficient was achieved of $\lambda_{u c_{A}}=29.18 \%,\left(E_{p_{u c_{A}}}=9.559 \mathrm{kWh}, E_{r_{u c_{A}}}=2.789 \mathrm{kWh}\right)$. The ride lasted 27.5 minutes. In order to better understand the values of $\lambda_{u c}$, we will list the results of measurements 

and impact on energy efficiency

performed on the city line No.29 (Dorćol-Medaković III). In the test conducted with the Ebus (Higer KLQ6125GEV3) on the line No.29 (Dorćol-Medaković III) the degree of recovery expressed through the ratio of the regenerated and total electricity consumed achieved in the direction "B" is $33.77 \%$ [5]. If compare the obtained values of the recuperation coefficient on line EKO 1 and line No.29, where the direction "B" is declining for most of the route (about $70 \%$ of the line) and where is the maximum a drop of the road section $5.5 \%$, E-bus has a significantly higher recovery rate achieved.

\section{CONCLUSIONS}

Based on the presented measurement methodology the acquisition of current values of current and voltage via BMS control unit E-bus (Higer KLQ6125GEV3) in real operating conditions on the line EKO 1, it was concluded that the highest degree of recovery is expressed through the ratio of recovered energy to supercapacitor and total consumption electricity from the supercapacitor, achieved in the direction "A" is $28.55 \%$, while the maximum value in the direction "B" is $19.57 \%$.

From the point of view of the impact on the achieved degree of recuperation and electricity consumption, it is important to point out that in the direction "A", from stations Zeleni venac-Block 21 , has a constant drop of about $2.1 \%$ on a section of about $1.9 \mathrm{~km}$. In the direction "A", the number of transported passengers is smaller, on the section in decline there are fewer resistance forces that occur in the phase of the movement which has an impact on less consumed electricity in the direction of "A".

In the mentioned section over Branko's bridge, the E-bus achieves the maximum speed of movement so that the maximum utilization of the kinetic energy of the E-bus during regenerative braking is possible, which is reflected in the amount of regenerated electricity returned to the supercapacitor. In the direction "B", the load of the E-bus is higher on the mentioned section, as well as the resistance forces of the movement, which affects the higher required electricity for movement. The ascending route and the lower maximum speed that is reached on the section over Branko's bridge affect the lower possibility of electricity recovery compared to the movement in the direction "A". It is obvious that the size of the recovery coefficient under the assumption that the regenerative braking system is used correctly is mostly influenced by the terrain configuration i.e. the presence of a road sections with decline.

\section{ACKNOWLEDGMENTS}

This paper is part of the research in the doctoral dissertation "Energy and environmental performance of electric buses in the passenger transport system", which is in the process of making, by the author Slobodan Mišanović. The author thanks everyone who helped in the realization of the research. Also, the paper is the result of the researches within the project TR 35041 that is supported by the Ministry of Education, Science and Technological Development of the Republic of Serbia.

\section{REFERENCES}

[1] Kotiev, G., Butarovich, D., Kositsyn, B.: "Energy efficient motion control of the electric bus on route", IOP Conf.Series:Materials Science and Engineering, 315, 012014, 2018. DOI: 10.1088/1757-899X/315/1/01/2014.

[2] Higer: Electric bus KLQ6125GEV3 - Technical documentation, 2016. 
[3] Mišanović, S., Živanović, P., Savković, D., Krstić, P., Ivanov, S., Stević, S.: “Twoyear successful exploitation of the electric buses in Belgrade", Mobility \& Vehicle Mechanics, 2019, Vol. 45, No. 1, pp. 17-27. DOI: 10.24874/mvm.2019.45.01.02.

[4] Blagojević, I.,Popović, V., Mitić, S., Vorotović, G., Stamenković, D., Ivanković, I., Miličić, B., Maljković, M., Frlić, N., Žunjić, M., Ivanov, S., Mišanović, S.: "Projekat istraživanje uticaja stila vožnje na energetsku efikasnost kod autobusa na elektirčni pogon”, Mašinski fakultet u Beogradu, 2020. godina. Naručilac projekta Gradska Uprava Beograd-Sekretarijat za javni prevoz.

[5] Mišanović, S., Glišović, J., Taranović, D., Pešić, R.: "Electric energy consumption and recuperation on E-bus in different exploitation conditions", 18th Symposium on Thermal Science and Engineering of Serbia, October 17 - 20, Sokobanja, Serbia, 2017, pp. 961-976. 